Article

\title{
Looking for the European Voter: Split-Ticket Voting in the Belgian Regional and European Elections of 2009 and 2014
}

\author{
Camille Kelbel ${ }^{1}$, Virginie Van Ingelgom ${ }^{2, *}$ and Soetkin Verhaegen ${ }^{3}$ \\ ${ }^{1}$ CEVIPOL, Université Libre de Bruxelles, 1050 Bruxelles, Belgium; E-Mail: camille.kelbel@ulb.ac.be \\ ${ }^{2}$ F.R.S.-FNRS, ISPOLE, Université Catholique de Louvain, 1348 Louvain-La-Neuve, Belgium; \\ E-Mail: virginie.vaningelgom@uclouvain.be \\ ${ }^{3}$ Centrum voor Politicologie, KU Leuven, 3000 Leuven, Belgium; E-Mail: soetkin.verhaegen@soc.kuleuven.be \\ * Corresponding author
}

Submitted: 5 October 2015 | Accepted: 8 January 2016 | Published: 29 February 2016

\begin{abstract}
While European elections are often seen as remote from EU issues, considerations specifically linked to the EU came to the forefront in the wake of the 2014 European elections: the economic and financial crisis, the new process of designation of the European Commission President, and the alleged increase of Eurosceptic votes. This increased salience of political debates about the EU asks for a reconsideration of the 'second-order nature' of European elections. In this context, as in 2009, the Belgian electorate voted for the regional and European levels on the very same day. Belgian voters were thus offered the opportunity to split their ticket between both levels. This allows comparing the occurrence and determinants of these 'immediate switching' behaviours in 2014 with those of the presumably less politicized EP elections in 2009. We do that by employing the 2009 and 2014 PartiRep Election Study data. On the one hand, the article shows that split-ticket voting cannot be explained by economic voting, European identity, and attitudes towards integration in 2014. On the other hand, the unique configuration of the Belgian elections enables us to observe that the introduction of Spitzenkandidaten did enhance split-ticket voting for voters who could directly vote for this candidate (in Flanders), while this did not increase split-ticket voting among voters who could only indirectly support the candidate (in Wallonia).
\end{abstract}

\section{Keywords}

economic voting; European elections; politicization; split-ticket voting

\section{Issue}

This article is part of the issue "How Different Were the European Elections of 2014?", edited by Wouter van der Brug, Katjana Gattermann and Claes de Vreese (University of Amsterdam, The Netherlands).

(C) 2016 by the authors; licensee Cogitatio (Lisbon, Portugal). This article is licensed under a Creative Commons Attribution 4.0 International License (CC BY).

\section{Introduction}

In multi-level political systems, voters are offered the opportunity to cast votes for several elections. These different contests are, however, not independent from each other. Sub-national and supra-national elections in Western European countries are bound to be tainted by national level considerations both in political campaigns and their electoral outcomes. If sub-national and supra-national elections have been introduced in an attempt to provide more legitimacy to these tiers of government, such legitimacy claims rest on the unproven assumption that voters vote according to levelspecific motives. In the case of the European Union (EU), scholars have often shown that elections for the European Parliament (EP) are simply not about Europe (Reif \& Schmitt, 1980; Føllesdal \& Hix, 2006). Due to low levels of politicization of European integration, EU issue voting is often considered, at best, a 'sleeping giant' (Van der Eijk \& Franklin, 2004; de Vries, 2007). At 
the same time, however, the integration process has resulted in a shift of a broad range of competences to the supra-national level. Few political domains are not affected by EU-level decision-making: Europe is nearly everywhere. This article aims to increase insights into the ways in which voters deal with this apparent paradox. What are EP elections about according to citizens? Are they about Europe at all? And if so, what specific EU issues are at stake?

In Belgium, electoral results of the 2014 EP elections clearly differed from those of the 2009 elections (see Table 1). Differences in party choices, however, do not tell us how and why these elections were different from previous contests. To answer these questions, we should shed light on vote motives.

Table 1. Results of the 2009 and 2014 EP Elections by region (\%). Source: verkiezingen2014.be

\begin{tabular}{lcrc}
\hline & $\mathbf{2 0 0 9}$ & $\mathbf{2 0 1 4}$ & Difference \\
\hline Flanders & & & \\
CD\&V & 23.54 & 20.14 & -3.40 \\
Groen & 7.84 & 10.57 & +2.73 \\
N-VA & 9.71 & 26.91 & +17.20 \\
Open VLD & 20.02 & 19.92 & -0.10 \\
PvdA+ & 1.01 & 2.42 & +1.41 \\
sp.a & 13.60 & 13.24 & -0.36 \\
Vlaams Belang & 15.82 & 6.80 & -9.02 \\
Wallonia & & & \\
cdH & 13.42 & 11.65 & -1.77 \\
Ecolo & 22.00 & 10.90 & -11.1 \\
FDF & $/$ & 2.27 & +2.27 \\
MR & 24.78 & 27.44 & +2.66 \\
PP & $/$ & 6.64 & +6.64 \\
PS & 30.50 & 29.66 & -0.84 \\
PTB-GO & 1.19 & 5.68 & +4.49 \\
\hline
\end{tabular}

Note: Percentages of vote share within each region are presented.

Given the simultaneity of the two types of elections, both in 2009 and in 2014, this article studies split-ticket voting between European and regional elections. Splitticket voting refers to voting for different parties for different offices which are being decided upon in a single election day. In 2014, the highest aggregate level effects of split-ticket voting between regional and EP elections were observed for the Open VLD (which scored 5.7 per cent higher in European elections), the N-VA (which scored 5.0 per cent lower in EP elections), the $\mathrm{cdH}$ (with a 3.5 per cent difference), and Ecolo (+2.3 per cent in EP elections). To understand the rationale of split-ticket voting, however, it is necessary to further explore its determinants at the individual-level.

In this study, we use the Belgian case to examine motives of differentiated vote choices between European and other (here: regional) elections. As in most of the EU (and especially Eurozone) member states, the economic and financial crisis was high on the political agenda in Belgium. Besides that, the Belgian case also provides a unique opportunity to test whether the introduction of Spitzenkandidaten had an effect on voting behaviours. Since the Dutch and French language communities in Belgium have separate party systems (Brack \& Pilet, 2010), and as a Spitzenkandidat was only running as a MEP candidate in the Dutch language community, we can test the effect of this new mechanism introduced in the 2014 EP elections in two different situations. Citizens of the Dutch language community could directly vote for this candidate; citizens of the French language community could only indirectly support this candidate. This peculiar situation is undoubtedly the main added value of the Belgian case to our attempt to explore new possible reasons for splitticket voting in EP elections. It enables us to test to what extent the newly introduced electoral connection between EP elections and the designation of the President of the European Commission-often seen as the ultimate attempt to introduce a 'quasi-parliamentary system' (Hobolt, 2014, p. 1532)-has gained any consideration among those it was directed at: the European citizens.

Thus, this article contributes to the debate of the (alleged) growing politicization of EU integration (de Wilde, 2011). It argues that because of the increased salience of European issues prior to the 2014 elections (the economic and financial crisis, the introduction of Spitzenkandidaten and more generally the alleged ongoing politicization of EU integration), voters are expected to have based their EP vote more often on European-specific motives rather than on considerations related to national or regional politics. Voting for a different party in EP elections than in other contests should increasingly be the result of EU-specific vote motives. Accordingly, this article tests whether reasons for split-ticket voting in 2014 differed from reasons for split-ticket voting in 2009.

\section{Split-Ticket Voting: Theory and Hypotheses}

\subsection{Explaining Split-Ticket Voting}

Split-ticket voting has originally been examined in the American two-party system, where several 'classical' explanations for ballot-splitting have been put forth. Differentiated vote choices in concurrent elections can first and foremost be linked to the general trend toward candidate-centred politics. On the one hand, split-ticket voting has been seen as the result of specific trends of the party system such as declining party loyalty, the weakening of party apparatuses, mediacentred campaigns, or the surge in incumbents' advantage (Wattenberg, 1991). On the other hand, funding, visibility, or the quality of a candidate (and notably his/her political experience-Jacobson, 1990) can result in voting for a particular candidate, even though 
this candidate is part of a different party than the one usually supported by a given voter (Beck, Baum, Clausen, \& Smith, 1992; Burden \& Helmke, 2009; Burden \& Kimball, 1998; Roscoe, 2003). Hence, both features of the system and of particular candidates can lead to 'candidate effects' resulting in split-ticket voting. Another set of explanations more simply suggests that voters look for different things in different elections (Jacobson, 1990), thus expressing arena-specific votes. Party preferences would differ in the two arenas precisely because something else is at stake in the two different elections. An additional account of voters' choices is offered by the policy-balancing model (Alessina \& Rosenthal, 1995; Fiorina, 1992), whereby voters situated 'in between' two parties may choose to alternate their choices in order to maximize their policy preferences overall.

Ever since the first direct elections of the EP in 1979 , major differences in voting behaviour between European and other-above all, national-elections have been pinpointed. They have almost invariably been analysed through the prism of the 'second-order' model (Reif \& Schmitt, 1980). Although the model originally did not directly focus on split-ticket voting, it did put forth explanations related to divergent electoral outcomes in different electoral contests: European elections are marked by higher abstention levels, and better electoral results of small and opposition parties-as opposed to large and governmental ones. Why do voters vote differently in European elections? Voters are deemed to consider European elections as less important than first-order, national elections and are expected to use these supra-national elections to express opinions about national-level issues (Reif, 1984, 1985; Schmitt, 2005). It is assumed that domestic issues dominate European ones when it comes down to vote choices for European elections (Reif, 1984, 1985). This recognised absence of genuine European elections is one of the crucial elements of the endemic 'EU democratic deficit': "European Parliament elections are [not] really 'European' elections: they are not about the personalities and parties at the European level or the direction of the EU policy agenda" (Føllesdal \& Hix, 2006, pp. 535-536). Developments of the model have tried to understand how national issues are mobilised in EP votes and result in differentiated votes. They have highlighted specific voting behaviours such as 'sanctioning the government' (Hix \& Marsh, 2007), or 'sincere voting' as opposed to the 'useful' votes expressed in national elections (Marsh \& Mikhaylov, 2010).

The second-order model thus accounts for different electoral outcomes in different electoral contests, through national vote motives. At the same time, the literature has increasingly come to acknowledge that European elections are to some extent about Europe (de Vries \& Tillman, 2011; Mattila, 2003; Schuck, Xezonakis, Elenbaas, Banducci, \& de Vreese, 2011), and much more so than they previously were (Hobolt, Spoon, \& Tilley, 2009). This apparent paradox can be solved by reconsidering the main assumption of the 'second-order' model, which states that domestic issues dominate, but do not necessarily monopolise the European electoral arena. Hence, the question becomes: how different vote motives pertaining to different levels are articulated in explaining votes in European elections, compared to other (first-order) elections.

The Belgian case offers an opportunity to reconsider this model in instances of simultaneous elections. Based on the above presented literature on split-ticket voting and on the 'second-order' model, we assume that voters who vote differently in two (or more) concomitant contests use a specific reasoning when casting a vote for the 'less important' contest (here: European elections). We can thus put forth explanations of why certain voters choose to vote differently in EP elections than in more 'first-order' elections: national elections, which remain the main reference point, but also regional elections. Furthermore, a number of structural and contextual characteristics of the Belgian political system challenge some of the core features of the 'second-order' model, which makes the country a good case for studying whether the changed context in which the EP elections took place in 2009 and 2014 affected split-ticket voting.

First, regarding the structural characteristics of the system, while lower participation levels in European elections is one of the three main pillars on which the model is based, compulsory voting in Belgium annihilate most interpretations regarding participation. Second, in multipolar systems like Belgium, a number of medium size parties enter electoral competition, blurring the differentiation between small and large organisations, which constitute the first reference of the model in terms of vote transfers. Third, as a 'consociation' that consists of governments at various policylevels, many parties usually take part in government at one level or the other. As a consequence, there is often no clear 'alternation' in power and the distinction between governmental and non-governmental parties is curtailed. Accordingly, voting behaviours which rest on the assumption that voters have clear pictures of who governs and who is likely to govern-such as 'sanctioning the government' or 'tactical voting' - are less likely to occur. A final structural characteristic of the Belgian case is that, as a federal state, the importance of the different regions brings into question the originally admitted dichotomous distinction between national first-order elections and a second-order category encompassing all other contests. In fact, the degree of importance that voters attach to regional elections has been shown to vary with the distribution of competences between the central state and the regions (Chhibber \& Kollman, 2004). The more competences attributed to the regions, the more likely it is that re- 
gional elections will escape the logics of secondorderness (Jeffery \& Hough, 2009). In federal or quasifederal states, where regions exert a real legislative power, voters tend to give more consideration to their regional elections. These contests should be considered on a continuum as less of second-order or even more of 'first-order' nature (Cutler, 2008; Jeffery \& Hough, 2009; Van der Eijk, Franklin, \& Marsh, 1996). Belgium is precisely a highly decentralized federal state in which the regions (and communities) have been attributed extensive competences ${ }^{1}$. Its regional elections can hence be reasonably assumed to escape the 'second-order' ranking and the choice of voters is likely to be largely influenced by factors specific to regional politics. As such, regional considerations should be brought in as part of the (first-order) explanation of ticket-splitting.

Secondly, and turning to contextual features, the initial model has often carefully ignored instances of simultaneous elections, although later research has reincorporated them (Heath, McLean, Taylor, \& Curtice, 1999; Van Aelst \& Lefevere, 2012). Electoral cycles, however, are part and parcel of the model. The sanctioning effect is expected to be stronger when European elections act as 'intermediary elections' (Parodi, 1983) or as 'mid-terms' (as in the 'punishment and protest' explanation of Hix \& Marsh, 2007). By contrast, sanctioning behaviour is expected to be weaker when EP elections are held closer to first-order ones-either directly after or just before-suggesting that there would be less vote-switching or even bonuses for governing parties in such instances (Reif, 1985). In this regard, Belgian voters have been confronted with an extreme case of such closeness in both 2009 and 2014.

In sum, with its consociational, federal and multiparty system, and taking into account the concomitance of elections, Belgium is clearly a 'least likely case' of voting behaviours in European elections dictated by the logics of the 'second-order' model. These characteristics theoretically limit the sanctioning effect to a large extent, leaving space for other-issue drivenvote motives. In the Belgian case it is more likely that a split vote is based on EU-specific considerations rather than on national considerations. If voters would take first-order preferences into account, they are expected to vote for the same party in both elections.

This article questions to what extent European elections are still of 'second-order' by examining whether split-ticket voting can be at least partly and increasingly linked to EU-specific motives. Hobolt et al. (2009)

1 The Sixth State Reform has most recently (2011-2013) proceeded with a considerable transfer of competences and has given broad fiscal autonomy to the regions, largely resulting in moving the centre of gravity of public policies from the Federal Government to the federated entities (Sautois \& Uyttendaele, 2013). showed that voters might base their votes on both European and domestic issues. Hence, both vote motives are not mutually exclusive. In 2009, Van Aelst and Lefevere (2012) studied why people voted differently in the 2009 regional and European elections in Belgium. They showed that at least a part of the electorate was driven by Euro-specific motivations. Our study contributes to this debate by introducing a comparison between 2009 and 2014, hence allowing for a first appreciation of a possible evolution. Such evolution is expected for two main reasons: EU matters are increasingly salient, and attitudes regarding (especially against) current developments of the EU have gained considerable attention. We expect that:

H1: Motives of split-ticket voting are likely to differ between 2009 and 2014. In 2014, split-ticket motives were more likely to entail EU-specific considerations.

\subsection{Looking for EU-Specific Motives}

This article studies why voters split their ticket, examining the extent to which EU-specific motives can be part of the explanation of such behaviour in the context of what are usually considered as 'second-order' elections. This second section first puts forth EU arena-specific considerations before turning to candidate effects explanations. As such, we offer a continuation, a test, and an addition to previous studies on voting behaviour in EP elections. Far from dismissing the 'second-order' model, we reassess it in light of a 'least likely case'. By reviewing EU-specific motives, this article tackles the question whether the increased salience of European issues prior to the 2014 elections due to the economic and financial crisis, the introduction of Spitzenkandidaten, and thus the alleged ongoing politicization of EU integration influenced motives for split-ticket voting in EP elections. In these posited more politicized EP elections, voters are expected to have based their vote more often on European-specific motives than on considerations related to national or regional politics.

\subsubsection{Reincorporating Arena-Specific Considerations}

EU-specific considerations can drive split-ticket voting. Carruba and Timpone, for instance, suggested that 'Europe matters' in the sense that voters actively express different preferences at the EU level and at the national level (Carruba \& Timpone, 2005, p. 279). They showed that voting for a green party at the European level could not be reduced to a vote for a small party or against the government (as argued in the 'second-order' elections theory). In the same vein, Hong recently demonstrated that European considerations matter in vote switching towards niche parties for European elections (Hong, 2015). 'Europe' would thus have become a 
subject-matter of its own, politicized and important enough to constitute a factor of voters' decisions in elections (de Vries \& Tillman, 2011; de Vries, van der Brug, van Egmond, \& van der Eijk, 2011; Hobolt \& Wittrock, 2011). In other words, Europe as an issue may constitute one motivational basis for choosing a particular party. Reasonably, if European issues had played a role in voters' decision, they would primarily have been expressed at that level, likely resulting in split-ticket voting.

One factor possibly leading to an EU-specific vote in EP elections (and to one that differs from one's vote in other elections) is the strength of an individual's European identity. The importance attributed to a specific ballot can be linked to perceptions of the institution, and specifically to how voters perceive the institution as legitimately representing them (Rohrschneider \& Loveless, 2011). As citizens with a stronger European identity feel part of the community that is (aimed to be) represented by the EP, those citizens with a stronger European identity are expected to attach more importance to EP elections (Verhaegen, 2015). As a result, voters with a stronger European identity are expected to more often specifically think about their policy preferences for the EU community they are part of when casting their vote in EP elections.

Another EU-related reason to vote differently in EP elections than in other elections are attitudes about EU integration. A considerable amount of recent studies suggests that EU attitudes increasingly affect party choice in EP elections (de Vries, 2007, 2009, 2010; de Vries et al., 2011; Evans, 1998, 2002; Hobolt et al., 2009). Eurosceptic votes linked to worries about the effects of EU policy and dissatisfaction with mainstream politics lie at the heart of Eurosceptic parties' success (Treib, 2014). In a context characterized by greater politicization, it is more likely that attitudes towards the EU influence electoral decisions. This process whereby the EU has become an issue in itself is referred to as 'EU issue voting' by de Vries (2007). Hence, it seems logical to assume that split-ticket voters may be turning to other parties in EP elections out of a positive or negative general attitude towards the $\mathrm{EU}^{2}$. As such, ticketsplitting could be attributed to various attitudes of the electorate towards different contests that are held simultaneously, but can also be attributed to different motives much in line with the arena-specific vote motives argument (Jacobson, 1990).

\footnotetext{
2 Note that the literature has underlined the need to consider citizens who are neither Europhile nor Eurosceptic as well (de Vries, 2013; Duchesne, Frazer, Haegel, \& Van Ingelgom, 2013; Rose \& Borz, 2015; Stoeckel, 2013; Van Ingelgom, 2012, 2014). Citizens that are indifferent and/or ambivalent towards European integration could be expected either to be more volatile and split their ticket or not to participate (the latter not really applying in Belgium due to compulsory voting). However, we lack indicators, as questions measuring indifference and ambivalence were not included in the surveys.
}

Besides these diffused factors of identity and attitudes about EU integration, policy-issues may also lead to an EU-specific vote. By 2014, some policy areas such as the economic and monetary union, security, migration, or the environment gained unprecedented salience. Kriesi and Grande (2015) showed that events such as the Greek crisis and bailout, the Irish bailout, and the fiscal compact translated into an increased salience of the EU in media coverage and in the public debate. Hobolt and Tilley (2014) also established that this increased salience of the Euro crisis translated into an increased awareness among citizens about the Euro crisis. Citizens even tended to perceive the EU as responsible for the economic situation in their country, rather than seeing this as a responsibility of the national government. To this regard, a particularly prolific theory, economic voting ${ }^{3}$, is precisely concerned with the impact of economic perceptions or situations on the probability of voting for incumbents or for any other party (Duch \& Stevenson, 2006). The economic voting phenomenon has often been studied through the vote function (Kramer, 1971; Lewis-Beck \& Stegmaier, 2000), which refers to the evolution of the vote for incumbents or for other parties, and entails both economic and political variables as explanations of vote choices (Nannestad \& Paldam, 1994). Applying economic voting to European elections entails that voters who associate economic matters with the EU are expected to vote for European elections based on economic considerations since they perceive the EU-level as particularly relevant on these matters. This may lead to voting for a different party in EP elections, than in national or regional elections, as the consideration for the economy is in this case made specifically about the EU-level.

Overall, we argue that especially for the 2014 EP elections, a number of EU arena-specific considerations are potential explanations of split-ticket voting. Thus, motives related to the EU or European politics are expected to increase the likelihood of voting differently in regional and EP elections in Belgium (Van Aelst \& Lefevere, 2012, p. 6). More precisely, we expect that:

H2a: Voters with a stronger European identity are more likely to split their ticket, especially in 2014.

$\mathrm{H} 2 \mathrm{~b}$ : Voters with more positive attitudes about EU integration are more likely to split their ticket, especially in 2014.

H2c: Voters who grant more importance to the economy are more likely to split their ticket, especially in 2014.

\footnotetext{
${ }^{3}$ For literature reviews of economic voting theory see, among others: Lewis-Beck (1990), Norpoth, Lewis-Beck, \& Lafay (1991), Dorussen \& Taylor (2001).
} 
We will further explain and explore these relationships in the third part of the article.

\subsubsection{Candidate Effects}

A number of authors have argued that limited levels of candidate voting in EP elections contribute to the absence of genuinely 'European' elections (Føllesdal \& Hix, 2006). In 2014, however, the first application of a provision enshrined in the Treaty of Lisbon has brought expectations of change in this regard. As of 2014, the elections of the EP should be taken into account by the European Council in the designation of the President of the European Commission (art.17 TEU). The interpretation put forth by the European Parliament is that the President of the Commission is to come from the party group that received the largest vote share in the European elections, urging political parties at European level (the so-called 'Europarties') to designate their 'lead candidate $^{\prime 4}$. The Europarties and the Parliament advertised that a vote for a particular party in the EP elections implies a vote for the 'lead candidate', or 'Spitzenkandidat', of the corresponding Europarty. Hobolt (2014) observed that the awareness about this electoral connection between a vote for the EP and the selection of a new President of the European Commission differed between member states where voters could directly vote for such a candidate (i.e. where a 'lead candidate' of a given Europarty was also a candidate to the EP for a national party), and member states where only the mechanism of indirect support for a candidate was possible.

In Belgium, although Guy Verhofstadt was known as former Prime Minister in 2009, we can assume that his visibility-at least partly attributable to his role as group President of the ALDE - in the past EP legislature (2009-2014) has established him as a major European figure. Switching to Verhofstadt would hence be in line with the 'candidate-effect' identified by the split-ticket voting literature. Although we cannot clearly establish whether voting for him is based on clear 'European motives' or tainted with considerations about the role of Belgium in Europe if Verhofstadt would become the President of the Commission (which would amount to a kind of strategic voting), both possibilities are linked to European considerations. In the Dutch-speaking community in Belgium, the candidate of the ALDE party for the Commission Presidency was on the Open VLD list. Thus, Verhofstadt's candidacy for President of the Commission is expected to have a (candidacy) effect on split-ticket voting. Following the literature on candidacy effects, it can be expected that Verhofstadt's candidacy encouraged part of the Flemish voters to vote for

\footnotetext{
${ }^{4}$ European Parliament, Resolution of 22 November 2012 on the elections to the European Parliament in 2014 (2012/ 2829(RSP)).
}

Open VLD and specifically to vote for Verhofstadt in EP elections, even if they voted for a different party in regional elections. In the French language community, voters who want to support Verhofstadt's candidacy for President of the Commission can be expected to vote for MR as this indirectly supports the candidacy of Verhofstadt (MR is also part of the ALDE Europarty). According to this reasoning, voters who turned to Open VLD or MR in the 2014 EP elections were more likely to do so for EU-specific motives, and more precisely for a specific 'European' candidate. Because of this, we expect that:

\section{H3a: Voting for Open VLD or MR in EP elections more often led to a split-ticket vote.}

$\mathrm{H} 3 \mathrm{~b}$ : Voting for Verhofstadt in EP elections more often led to a split-ticket vote among voters of the Dutch language community.

\section{Data and Methods}

The data of the PartiRep Elections Study 2009 and $2014^{5}$ are used in this article as they allow for comparing explanations for split-ticket voting between the two most recent EP elections. In these studies, a geographically stratified random sample of eligible voters in Flanders and Wallonia was drawn from the national registry. The 2009 study was carried out in three waves, two before and one after the elections of June 7th, 2009. The 2014 study was carried out in two waves, one before and one after the elections of May 25th, 2014. Different respondents participated in the 2009 and the 2014 study. While a short panel study was carried out in both election years, it has to be noted that we do not use panel data from 2009 to 2014. In the first wave of each study, respondents were interviewed face-to-face about their personal background, opinions, interests, political activities, and voting behaviour. In the other survey waves, the respondents were interviewed by phone about the votes they casted, their vote motives, and the election campaign. In 2009 , the first interview was completed by 2,331 respondents (1,204 Flemish and 1,127 Walloon), 1,845 respondents completed the survey in the second wave, and 1,698 respondents also completed the third survey. In 2014 , the interview was completed by 2,019 re-

\footnotetext{
${ }^{5}$ We use the PartiRep Election Study 2009 and 2014. PartiRep is a network and a research project focusing on changing patterns of participation and representation in modern democracies. PartiRep is formally an Interuniversity Attraction Pole (IAP) funded by the Belgian Science Policy (Belspo). It involves the universities of Antwerp (Universiteit Antwerpen), Brussels (Vrije Universiteit Brussel and Université libre de Bruxelles), Leiden (Universiteit Leiden), Leuven (KU Leuven), Louvain-LaNeuve (Université Catholique de Louvain), and Mannheim (Universität Mannheim).
} 
spondents (1,008 Flemish and 1,011 Walloon), which accounts for an acceptable response rate of 45 per cent. In the second wave, 1,470 respondents completed the survey. To account for the disproportionate non-response rate according to age, gender, and education level, weights are used throughout the analyses. Indicators for the concepts of interest in this research (European vote motives, economic vote motives, and information on voting for a Spitzenkandidat) are included in the data.

In both studies, respondents were asked which topic they find most important to take into account when deciding upon their vote. In the 2009 study, 'the financial crisis' was in the list of options. In 2014, 'economics' was included as an option. These questions are used as measures for economic motives for split-ticket voting. As measures for European vote motives, attitudes about EU integration, and European identity are included. Attitudes about EU integration are measured on a scale from 0 to 10 whereby ' 0 ' means respondents think that European integration already went too far, ' 5 ' that it is fine as it is, and ' 10 ' that they would like the EU to further integrate. European identity is measured by asking respondents to which geographic or cultural community they feel they belong to in the first place and in the second place. A dummy variable is constructed with the respondents who opted for Europe in the first place or in the second place receive code ' 1 ', and respondents that did not choose Europe receive code ' 0 ' 6 . Voters with a stronger European identity are expected to attach more importance to EP elections (Bruter, 2008; Ehin, 2008; Verhaegen, 2015). As a result, they are expected to invest more consideration in their vote for the EP, which is more likely to result in a split-ticket vote based on EU vote motives. On the contrary, voters with a strong regional identity might focus on regional elections and just follow the same line in EP elections, which they perceive as less important in comparison to voters with a strong European identity. Also, regional identity is included as a dummy variable (using the same survey questions about feeling of belonging to particular geographic and cultural communities) to set the effect of European identity against the potential effect of regional identity. The hypothesized effect of the introduction of Spitzenkandidaten requires an extra test of the effect of voting for a specific candidate. To examine the effect on split-ticket voting of the fact that former Belgian Prime Minister Guy Verhofstadt was running as Spitzenkandidat for the ALDE, we tested whether respondents who voted for a liberal party (Open VLD among Flemish respondents and MR among Walloon

\footnotetext{
${ }^{6}$ As a robustness test, we replicated the analysis of the 2014 data with a more elaborate measure of European identity. This analysis led to the same result as when using the binary variable: European identity is not significantly related to split-ticket voting.
}

respondents) were more likely to have also split their ticket. Also, in 2014 we assessed whether the candidate effect (if any) in Flanders can be explained by specifically voting for Verhofstadt.

We also introduced other variables in order to check for alternative explanations of split-ticket voting. A first alternative explanation is uncertainty of party preference or of allegiance. It is expected that when voters like multiple parties or are not strongly attached to just one party, they might vote for different parties in different elections (here: regional and European) in order to express their support for different parties. This is also seen as 'balancing' between different preferences and positions (Giebler \& Wagner, 2015). On the one hand, this can be measured by vote switching between the election that took place during the study, and the most recent previous election. On the other hand, an indicator is included that displays whether the vote intention of the respondent in the first wave of the study matches the vote in the election. A comparison is made with the actual vote in the regional election of 2009 and 2014 respectively because the questions about the vote choice in the most recent previous election, and about vote intention, were measured for regional and federal elections only, which are theoretically of or closer to first-order classification. This information is not available for voting in EP elections. A second alternative explanation for split-ticket voting is voting for a specific candidate, rather than for a party. The specific characteristics of a candidate might attract support of a voter, quasi-independently from which party the candidate is attached. This might lead to split-ticket voting as the party of the candidate is seen as of little importance. In the 2009 study, respondents were asked about their vote motives for EP elections in an open question. We use the coding of Van Aelst and Lefevere (2012) who attributed the code ' 1 ' to respondents who referred to a specific candidate in their vote motive. Respondents who did not mention a candidate or candidates received the code ' 0 '. In the 2014 study, respondents were directly asked whether they voted for the party in general, or for a specific candidate (or multiple candidates). A dummy variable is constructed where voting for a candidate received ' 1 '.

Finally, control variables are included in the analyses. Education level is included as individual resources, such as education level, influences political sophistication. Similarly, political interest and political knowledge are related to political sophistication. More sophisticated reasoning that combines different vote motives and strategies may drive split-ticket voting. Also, citizens with a higher educational level, who know more about politics and who are more interested in politics, are more likely to be in favour of EU integration and have a stronger European identity (Fligstein, 2008; Verhaegen \& Hooghe, 2015). Political sophistication could thus potentially moderate the relationship between attitudes 
about and identifications with the EU and split-ticket voting. Furthermore, controls are included for age, gender, and political trust. Political trust in national institutions might increase or decrease the odds of ticketsplitting as we have seen that EP vote can be used to support or sanction the (parties in) government. Citizens employ proxies rooted in attitudes towards domestic politics in their attitudes towards European integration (Anderson, 1998; Duchesne et al., 2013). Moreover, citizens who have more trust in political institutions tend to identify more strongly as European (Verhaegen \& Hooghe, 2015). Trust in political institutions could thus moderate as well the relationship between EU-specific vote motives and split-ticket voting.

\section{Analyses}

Table 2 presents the proportion of the respondents in the PartiRep Election Studies of 2009 and 2014 that split their ticket between regional and EP elections. In both election years, a large majority of citizens voted for the same party in regional and in EP elections.

Even though 18.59 to 28.99 per cent of the respondents split their ticket, it is more likely that one voted for the same party in both elections. It can also be observed that in both election years, Flemish voters were more likely to split their ticket than Walloon voters. Finally, we see that both in Flanders and in Wallonia more respondents split their ticket in 2014 than in 2009. Different vote motives might have inspired voters in 2014 and in 2009. This is in line with our first hypothesis.

In order to test whether split-ticket voting could be explained by different factors in 2014 than in 2009, multivariate logistic regressions will be carried out for both elections, including the same explanatory and control variables. The significance of the explanatory variables will be compared between both models. The analyses are carried out for Wallonia and Flanders separately as each region has a separate party system.

Table 2. Regional-European split-ticket voting in 2009 and 2014 in Flanders and Wallonia. Source: PartiRep Election Study 2009, 2014.

\begin{tabular}{lcccc}
\hline & \multicolumn{2}{c}{2009} & \multicolumn{2}{c}{2014} \\
\hline & $\%$ & $\mathbf{N}$ & $\%$ & $\mathbf{N}$ \\
\hline Flanders & $22.76 \%$ & $201 / 883$ & $28.99 \%$ & $225 / 776$ \\
Wallonia & $18.59 \%$ & $134 / 721$ & $26.94 \%$ & $167 / 620$ \\
\hline
\end{tabular}

Note: Percentages of split-ticket voting are presented. This is the proportion of respondents that voted for a different party in the EP elections than in the regional elections.

\subsection{Explaining Split-Ticket Voting between Regional and European Levels: Comparing 2009 and 2014 Ballots}

The multivariate logistic analyses that include all explanatory and control variables are presented in Table 3.
Similar (coded 0) or dissimilar (coded 1) party choices in regional and European elections as reported by the respondents are used as the dependent variable. These analyses show that not all bivariate relationships are robust when including control variables and alternative explanations. In the 2009 study in the Flemish sample, European identity and attitudes about EU integration show significant coefficients. In 2014, however, there is no significant relationship between European identity or support for EU integration and split-ticket voting in Flanders. Rather, uncertainty (i.e. changing party preference between the 2014 regional elections and the previous elections, and changing party preference between the 2014 regional elections and the first 2014 survey wave) and voting for a specific candidate in EP elections show to be consistent explanations for splitticket voting in both 2009 and 2014 in Flanders. In the Walloon sample, part of the variation in split-ticket voting in 2009 can be explained by uncertainty of party preference exemplified by intra-campaign vote switching (between the first and the last survey wave of the 2009 Study). Also, respondents who voted for a specific candidate in the 2009 EP elections were more likely to split their ticket. In 2014, the variance in split-ticket voting among Walloon respondents can be explained by both inter-campaign vote switching (between the 2007 and 2009 elections), and by intra-campaign vote switching. Voting for a specific candidate is not significantly related to split-ticket voting in Wallonia in 2014. Finally, voters who considered the economy as the most important issue when voting are not more likely to have split their ticket. All in all, our second set of hypotheses is largely invalidated.

\subsection{A Verhofstadt Effect in 2014?}

Five major Europarties designated candidates for the European Commission Presidency ahead of the European elections. One of them-the candidate of the ALDE-was the former Belgian Prime Minister, Guy Verhofstadt. A direct effect of his candidacy could be expected in Flanders where voters could directly vote for him, and an indirect effect in Wallonia where only the mechanism of indirect support could be at play through a vote for the MR (Mouvement Réformateur) party. Indeed, in Flanders, many respondents of our pool voted for Open VLD for the European elections even when they voted for a different party in the 2014 regional elections, thereby increasing the declared vote for this party by 5.4 per cent between regional and European elections. Thus, 16 per cent of the N-VA electorate, 11.6 per cent of CD\&V voters, 9.8 per cent of Sp.a voters, 12 per cent of the Groen electorate and 13.8 per cent of Vlaams Belang voters at regional elections split their vote, throwing their support at Open VLD at the European level. In Wallonia, the MR records similar results for both elections, respectively 26.7 per cent and 
Table 3. Explaining split-ticket voting between Regional and EP Elections in Flanders and Wallonia in 2009 and 2014. Source: PartiRep Election Study 2009 and PartiRep Election Study 2014.

\begin{tabular}{|c|c|c|c|c|}
\hline & $\begin{array}{c}\text { Model I } \\
\text { Flanders } 2009 \\
\end{array}$ & $\begin{array}{c}\text { Model II } \\
\text { Flanders } 2014 \\
\end{array}$ & $\begin{array}{c}\text { Model III } \\
\text { Wallonia } 2009\end{array}$ & $\begin{array}{c}\text { Model IV } \\
\text { Wallonia } 2014\end{array}$ \\
\hline & $\mathrm{b}(\mathrm{SE})$ & $\mathrm{b}(\mathrm{SE})$ & $\mathrm{b}(\mathrm{SE})$ & $\mathrm{b}(\mathrm{SE})$ \\
\hline \multicolumn{5}{|l|}{ Economic vote motive } \\
\hline $\begin{array}{l}\text { Economy/financial crisis most important } \\
\text { issue to decide vote }\end{array}$ & $0.030(0.242)$ & $0.344(0.256)$ & $0.094(0.278)$ & $0.748(0.383)$ \\
\hline \multicolumn{5}{|l|}{ EU-specific vote motives } \\
\hline European identity & $0.743(0.274)^{* *}$ & $0.309(0.310)$ & $0.494(0.329)$ & $0.596(0.472)$ \\
\hline Regional identity & $0.360(0.255)$ & $0.154(0.284)$ & $0.393(0.318)$ & $0.204(0.426)$ \\
\hline $\begin{array}{l}\text { Attitude about EU integration (higher score is } \\
\text { more positive towards further integration) }\end{array}$ & $-0.117(0.049)^{*}$ & $0.026(0.050)$ & $0.048(0.056)$ & $0.010(0.066)$ \\
\hline \multicolumn{5}{|l|}{ Alternative explanations } \\
\hline Change vote between elections & $0.898(0.242)^{* * *}$ & $0.869(0.268)^{* *}$ & $0.528(0.282)$ & $1.129(0.462) *$ \\
\hline $\begin{array}{l}\text { Change party preference between survey } \\
\text { waves }^{+}\end{array}$ & $1.733(0.246)^{* * *}$ & $1.362(0.281)^{* * *}$ & $1.824(0.297)^{* * *}$ & $1.575(0.432)^{* * *}$ \\
\hline Vote for candidate (vote for list is ref.) & $1.429(0.229)^{* * *}$ & $0.751(0.245)^{* *}$ & $1.006(0.346)^{* *}$ & $-0.059(0.340)$ \\
\hline Political trust (national institutions) & $-0.062(0.078)$ & $0.019(0.085)$ & $0.018(0.095)$ & 0.049 (0.109) \\
\hline \multicolumn{5}{|l|}{ Control variables } \\
\hline Age & $0.002(0.008)$ & $-0.015(0.007)^{*}$ & $-0.001(0.009)$ & $-0.001(0.011)$ \\
\hline Female & $-0.245(0.233)$ & $-0.519(0.275)$ & $-0.321(0.279)$ & $0.091(0.343)$ \\
\hline \multicolumn{5}{|l|}{ Education (low is ref.) } \\
\hline Middle & $0.372(0.318)$ & $0.470(0.325)$ & $0.403(0.377)$ & $-0.600(0.485)$ \\
\hline High & $1.020(0.341)^{* *}$ & $0.418(0.333)$ & $0.460(0.379)$ & $0.254(0.439)$ \\
\hline Political interest & $0.021(0.053)$ & $-0.056(0.059)$ & $-0.024(0.068)$ & $-0.059(0.063)$ \\
\hline Political knowledge & $0.202(0.085)^{*}$ & $-0.080(0.441)$ & $-0.053(0.098)$ & $0.065(0.607)$ \\
\hline Intercept & $-3.410(0.662)^{* * *}$ & $-1.945(0.726)$ & $-3.389(0.713)^{* * *}$ & $-2.855(0.908)^{* *}$ \\
\hline $\mathrm{N}$ & 661 & 439 & 487 & 326 \\
\hline Pseudo- $R^{2}$ & $23.47 \%$ & $17.38 \%$ & $19.32 \%$ & $19.84 \%$ \\
\hline
\end{tabular}

Note: Logistic regression with split-ticket voting as dependent variable. The results are weighted for age, gender and education level. ${ }^{*} p<0.05 ;{ }^{* *} p<0.01 ;{ }^{* * *} p<0.001 .{ }^{+}$In 2009 , respondents' vote in the regional elections is compared to their preference for the regional elections in the first wave; in 2014 party preference is not asked for the regional elections in wave 1 , so the actual vote in the 2014 regional elections is compared to respondents' preference for the federal elections in wave 1.

27.4 per cent in regional and European ballots. In this last section, we test if the running of former Belgian Prime Minister Guy Verhofstadt as Spitzenkandidat had an effect on split-ticket voting toward a candidate in 2014.

First, we observe no substantial difference when comparing percentages of respondents who declare to have voted for a specific candidate between Flanders (43.5 per cent) and Wallonia (43.8 per cent). Yet, voters mentioning voting for a specific candidate in EP elections (that is, casting one or multiple preference vote(s) rather than a vote for the entire list) were more likely to split their ticket in Flanders (34.3 per cent) than in Wallonia (24.3 per cent). Taking a closer look at who were the specific candidates the respondents casted their vote for, we observe that in Flanders, Guy Verhofstadt comes first with 32.5 per cent. In Wallonia, Louis Michel gathers 20.3 per cent. The descriptive results for the top three of specific candidates in Flanders and in Wallonia are presented in Table 4.

More importantly, in Flanders, the respondents who declare to have voted for the former Prime Minis- ter were more inclined to split their ticket between regional and European elections, as 55.8 per cent of those who gave their vote to Verhofstadt in the EP elections did not vote for Open VLD in regional elections. The fact that other popular politicians, such as Louis Michel (MR), Marianne Thyssen (CD\&V) or Marie Arena (PS), were less able to attract split-ticket voters is already an indication of what could be called a 'Verhofstadt effect' thus confirming hypotheses $3 a$ and $3 \mathrm{~b}$. In sum, it seems that voting in for Verhofstadt EP elections helps to explain split-ticket voting. In the next section we test whether this relationship is robust when including control variables and alternatives explanations.

In order to scrutinize the direct impact of the presence of a 'Spitzenkandidat' on the European list in Flanders, and to test for an indirect effect in Wallonia, we use a multivariate analysis again that combines the economic voting motives, the EU-specific vote motives, and alternative classical explanations. We also add indicators capturing a 'Spitzenkandidat' effect. Again, we use binary regression models to predict split-ticket voting (1) or straight-ticket voting (0). In a first step, we estimate two 
Table 4. Top three of specific candidates mentioned by the respondents in Flanders and Wallonia in EP Elections (first mentioned, N=551). Source: PartiRep Election Study 2014.

\begin{tabular}{|c|c|c|c|c|}
\hline & \multicolumn{2}{|c|}{ Electoral results in 2014} & \multicolumn{2}{|c|}{ PartiRep 2014 Survey } \\
\hline & $\begin{array}{c}\text { Preference } \\
\text { votes }^{+}\end{array}$ & $\begin{array}{c}\text { Percentage } \\
\text { of voters }\end{array}$ & $\begin{array}{l}\text { Split-ticket voters } \\
\text { (per cent) }\end{array}$ & $\mathbf{N}$ \\
\hline \multicolumn{5}{|l|}{ Flanders } \\
\hline VERHOFSTADT Guy (Open VLD) & 531,030 & 32.5 & 55.8 & 104 \\
\hline THYSSEN Marianne (CD\&V) & 340,026 & 15.0 & 27.1 & 48 \\
\hline VAN OVERTVELDT Johan (N-VA) & 274,444 & 11.6 & 5.4 & 37 \\
\hline Respondents declaring voting for a specific candidate & & & 34.3 & 320 \\
\hline \multicolumn{5}{|l|}{ Wallonia } \\
\hline MICHEL Louis (MR) & 264,550 & 20.3 & 25.5 & 47 \\
\hline ARENA Marie (PS) & 186,103 & 13.9 & 6.3 & 32 \\
\hline ROLIN Claude (CDH) & 75,521 & 10.0 & 21.7 & 23 \\
\hline Respondents declaring voting for a specific candidate & & & 24.3 & 231 \\
\hline
\end{tabular}

Note: Percentages of respondents mentioning specific candidates for those who declared a vote for a candidate and percentages of those mentioned one of the top three most-mentioned candidates that are split-ticket voters. ${ }^{+}$These data were computed by J. Dodeigne (Dodeigne, 2015).

models, one for each region, which includes a dummy variable voting for Open VLD in EP elections or voting for MR in EP elections. This variable accounts for the fact that a 'Spitzenkandidat' effect could have played a role in leading more voters to turn to Open VLD and to its French-speaking counterpart, in order to support the candidacy of Guy Verhofstadt in the race for the Commission Presidency. Indeed, the Belgian electorate was at least-partly-aware of his candidacy to the Presidency of the Commission. In the survey commissioned by the Alliance of European Conservatives and Reformists, 71 percent declared to be aware of the candidacy of Guy Verhofstadt when aided to answer the question (Alliance of European Conservatives and Reformists, 2014). Voters aware of his candidacy and willing to support it should have logically privileged the national parties that stand for the ALDE-in Flanders, Open VLD and in Wallonia, indirectly through the MR.

Models V and VI (see Table 5) confirm earlier presented results when introducing voting for Open VLD/MR in the models. In 2014, in both regions, neither economic vote motive nor EU-specific vote motives do significantly affect the odds of casting a split-ticket vote between regional and European ballots. The variances in split-ticket voting among respondents are related to both inter-elections vote switching and intra-campaign vote switching. More importantly, in Flanders, once we introduce voting for Open VLD, voting for a specific candidate rather than for a list does not significantly explain the probability of ticket-splitting any more. In other words, split-ticket voting can be significantly explained by voting for Open VLD at the European level. Respondents who voted for Open VLD in EP elections often voted for a different party in Regional elections. In Wallonia, we do not find any trace of an indirect mechanism of support for the candidacy of Guy Verhofstadt as a Spitzenkandidat through a vote for the MR.
In Model VII, we add a dummy variable to account for the declared vote for Guy Verhofstadt (1) or for (an)other candidate(s) (0) in Flanders. This last model hence verifies whether there was a 'Verhofstadt effect' on split-ticket voting in Flanders, even when controlling for the other identified motives of split-ticket voting. Declaring to have voted for Guy Verhofstadt is found to be a crucial explanation for split-ticket voting in Flanders in 2014. Also in this case, the effect of voting for a specific candidate in EP elections disappears at the expense of a strong and highly significant effect of voting for Verhofstadt. This result suggests that Flemish citizens who split their ticket did so in part because they specifically wanted to vote for Verhofstadt and possibly support his candidacy as Spitzenkandidat. This supports hypotheses 3a and $3 b$.

\section{Discussion}

Due to the differences between the context in which the 2014 and the 2009 EP elections took place, vote motives pertaining to both elections were expected to differ. More precisely, this article argued that European considerations should have mattered more in vote choices in 2014 and that this should be visible through increased levels of split-ticket voting. In the Belgian case, voters casted their vote for regional and EP elections on the same day. Hence, voters generally had the same attitudes and perceptions about the political and social situation when casting their different votes. We therefore tried to explain why voters did vote for a different party in the two ballots under scrutiny: the regional and the European ones. The results of our analyses show that the strength of respondents' European identity, and their support for EU integration, significantly explain split-ticket voting in the Flemish sample in 2009 , but not in the 2014 or in the Walloon samples. 
Table 5. 'Spitzenkandidat Effect' on Split-Ticket Voting between Regional and EP Elections in Flanders and Wallonia in 2014. Source: PartiRep Election Study 2009 and PartiRep Election Study 2014.

\begin{tabular}{|c|c|c|c|}
\hline & $\begin{array}{c}\text { Model V } \\
\text { Flanders } 2014\end{array}$ & $\begin{array}{c}\text { Model VI } \\
\text { Wallonia } 2014\end{array}$ & $\begin{array}{c}\text { Model VII } \\
\text { Flanders } 2014\end{array}$ \\
\hline & $\mathrm{b}(\mathrm{SE})$ & $\mathrm{b}(\mathrm{SE})$ & $\mathrm{b}(\mathrm{SE})$ \\
\hline \multicolumn{4}{|l|}{ Economic vote motive } \\
\hline $\begin{array}{l}\text { Economy/financial crisis most important issue to decide } \\
\text { vote }\end{array}$ & $0.185(0.261)$ & $0.719(0.392)$ & $0.196(0.264)$ \\
\hline \multicolumn{4}{|l|}{ EU-specific vote motives } \\
\hline European identity & $0.447(0.314)$ & $0.588(0.473)$ & $0.367(0.312)$ \\
\hline Regional identity & $0.302(0.297)$ & $0.209(0.425)$ & $0.393(0.318)$ \\
\hline $\begin{array}{l}\text { Attitude about EU integration (higher score is more } \\
\text { positive towards further integration) }\end{array}$ & $0.021(0.052)$ & $0.010(0.066)$ & $0.035(0.052)$ \\
\hline \multicolumn{4}{|l|}{ 'Spitzenkandidat' effect } \\
\hline Vote for candidate & $0.462(0.263)$ & $-0.069(0.341)$ & $0.224(0.286)$ \\
\hline Vote for Open-VLD/MR & $1.128(0.292)^{* * *}$ & $0.179(0.371)$ & \\
\hline Vote for Verhofstadt & & & $1.306(0.337)^{* * *}$ \\
\hline \multicolumn{4}{|l|}{ Alternative explanations } \\
\hline Change vote between elections & $0.829(0.274)^{* *}$ & $1.118(0.463)^{*}$ & $0.843(0.275)^{* *}$ \\
\hline Change party preference between survey waves ${ }^{+}$ & $1.315(0.289)^{* * *}$ & $1.594(0.438)^{* * *}$ & $1.344(0.288)^{* * *}$ \\
\hline Political trust (national institutions) & $0.039(0.090)$ & $0.054(0.110)$ & $0.014(0.090)$ \\
\hline \multicolumn{4}{|l|}{ Control variables } \\
\hline Age & $-0.011(0.008)$ & $-0.001(0.011)$ & $-0.111(0.008)$ \\
\hline Female & $-0.534(0.285)$ & $0.102(0.347)$ & $-0.443(0.282)$ \\
\hline \multicolumn{4}{|l|}{ Education (low is ref.) } \\
\hline Middle & $0.599(0.343)$ & $-0.642(0.493)$ & $0.564(0.333)$ \\
\hline High & $0.461(0.344)$ & $0.224(0.449)$ & $0.492(0.340)$ \\
\hline Political interest & $-0.045(0.060)$ & $-0.057(0.062)$ & $-0.048(0.060)$ \\
\hline Political knowledge & $-0.101(0.441)$ & $0.053(0.609)$ & $-0.013(0.439)$ \\
\hline Intercept & $-2.457(0.772)^{* * *}$ & $-2.926(0.930)^{* *}$ & $-2.224(0.762)^{* *}$ \\
\hline $\mathrm{N}$ & 439 & 326 & 439 \\
\hline Pseudo- $R^{2}$ & $20.50 \%$ & $19.91 \%$ & $20.17 \%$ \\
\hline
\end{tabular}

Note: Logistic regression with split-ticket voting as dependent variable. The results are weighted for age, gender and education level. ${ }^{*} p<0.05 ;{ }^{*} p<0.01 ;{ }^{* * *} p<0.001$. ${ }^{+}$As in 2014 party preference was not asked for the regional elections in wave 1, the actual vote in the 2014 regional elections is compared to respondents' preference for the federal elections in wave 1.

Rather, uncertainty about the most favoured party (which is often the result of holding multiple party preferences or of having a weaker party identification) and voting for a specific candidate in EP elections proved to be the most robust explanation for splitticket voting in both regions of Belgium and in both elections accounted for in this study. Uncertainty appears in line with classical de-alignment-based explanations of ticket-splitting, rather than as a change because of the specific context in which the 2014 EP elections took place. Voting for a specific candidate, also largely corroborates classical explanations of ticketsplitting, especially when considering the increasingly candidate-centred nature of the political system. Also, one could add that the structure of the ballot in Belgium (semi-opened lists), whereby the head of the list is often meant to 'pull the list'. As a result, to a large extent, logics pertaining to the national political context and party system have prevailed. Yet, emitting a preference vote for one (or several) candidate(s) can be driven by characteristics of the candidate(s) that remain linked to national-level considerations (e.g. when a candidate has had an important role at the na- tional or sub-national level before), or may be driven by European-level considerations (e.g. in cases when the candidate has a pronounced and visible opinion about EU policies and/or integration). While such differentiation remains difficult to interpret in 2009, the analyses demonstrated that in 2014 a candidate effect could be attributed to the specific presence on the lists of Guy Verhofstadt.

Our data provides mixed evidence for the claim that the 2014 EP elections were more dominated by European vote motives than previous EP elections. Both the financial crisis and the politicization of the EU have seemingly had a very limited effect on vote choices. The introduction of Spitzenkandidaten is, however, a notable exception and does seem to have had a direct effect. When Flemish voters switched to the liberal party for European elections, they were likely to tick the name of Verhofstadt. When voters could only indirectly support Verhofstadt's candidacy (as in Wallonia), no effect was found. This appears in line with the findings of Hobolt (2014) who observed that in member states which are the home country of one or more of the Spitzenkandidaten, more citizens were aware of 
the link between their vote and the selection of a new President of the European Commission. Our research adds to these observations that such a 'Spitzenkandidat effect' has an impact on voting. Moreover, the presence of a direct effect, while an indirect effect seems to be absent, pleas in favour of the idea of direct elections for the President of the European Commission as one reaction to weak interest in EP elections among lay citizens. Furthermore, our research shows how the differentiation between national and European vote motives is increasingly difficult to make. European elections in Flanders have at least to some extent been about a national personality as denounced by the 'democratic deficit' literature (Føllesdal \& Hix, 2006), while being at the same time about a major European figure. Critics of the second-order model have maybe been too quick in dismissing its central postulate. In the end, the issue is not so much about whether European vote motives matter in European elections but also about how they may combine with national ones.

The specificities of the Belgian case have hence largely allowed us to reconsider and further test the second-order model in the case of simultaneous elections. According to the Belgian Constitution following the Sixth State Reform, the federal elections should always be organised the same day as the European elections. Since their introduction, the regional elections have also been traditionally organised concomitantly with the European ballot. Although the regions do possess some leeway in adjusting the length of their legislatures and the date of elections, the Belgian case is likely to increasingly provide a prolific field of research for split-ticket voting in the future.

\section{Acknowledgements}

We would like to thank the editors of this special issue for gathering recent work around the topic of the latest EP elections. We would also like to thank the anonymous reviewers for their helpful comments and suggestions. Also, special thanks go to the PartiRep research network for letting us include a strong focus on EP elections in the PartiRep Election Study 2014 and to Peter Van Aelst and Jonas Lefevere for giving us access to their coding of 2009 dataset. Finally, this article was published thanks to the financial support of F.R.S. FNRS (under grant agreement number 1.C128.15).

\section{Conflict of Interests}

The authors declare no conflict of interests.

\section{References}

Alliance of European Conservatives and Reformists. (2014). Post EU Election polling project, AMR GmbH Dusseldorf, 25-26 May.
Alesina, A., \& Rosenthal, H. (1995). Partisan politics, divided government, and the economy. Cambridge: Cambridge University Press.

Anderson, C. J. (1998). When in doubt, use proxies: Attitudes toward domestic politics and support for European integration. Comparative Political Studies, 31(5), 569-601.

Beck, P. A., Baum, L., Clausen, A. R., \& Smith, C. E. J. (1992). Patterns and sources of ticket splitting in subpresidential voting. American Political Science Review, 86(4), 916-928.

Brack, N., \& Pilet, J.-B. (2010). One country, two party systems? The 2009 Belgian regional elections. Regional \& Federal Studies, 20(4-5), 549-559.

Bruter, M. (2008). The Europeans: Political identity in an emerging polity. West European Politics, 31(5), 1091 1092.

Burden, B. C., \& Helmke, G. (2009). The comparative study of split-ticket voting. Electoral Studies, 28(1), 1-7.

Burden, B. C., \& Kimball, D. C. (1998). A new approach to the study of ticket splitting. American Political Science Review, 92(03), 533-544.

Carrubba, C., \& Timpone, R. J. (2005). Explaining vote switching across first- and second-order elections: Evidence from Europe. Comparative Political Studies, 38(3), 260-281.

Chhibber, P., \& Kollman, K. (2004). The formation of national party systems: Federalism and party competition in Canada, Great Britain, India, and the United States. Princeton: Princeton University Press.

Cutler, F. (2008). One voter, two first-order elections? Electoral Studies, 27(3), 492-503.

de Vries, C. E. (2007). Sleeping giant: Fact or fairytale? How European integration affects national elections. European Union Politics, 8(3), 363-385.

de Vries, C. E. (2009). The Impact of EU referenda on national electoral politics: The Dutch case. West European Politics, 32(1), 142-171.

de Vries, C. E. (2010). EU issue voting: Asset or liability? How European integration affects parties' electoral fortunes. European Union Politics, 11(1), 89-117.

de Vries, C. E. (2013). Ambivalent Europeans? Public support for European integration in East and West. Government and Opposition, 48, 434-461.

de Vries, C. E., \& Tillman, E. R. (2011). European Union issue voting in East and West Europe: The role of political context. Comparative European Politics, 9(1), 1-17.

de Vries, C. E., van der Brug, W., van Egmond, M. H., \& van der Eijk, C. (2011). Individual and contextual variation in EU issue voting: The role of political information. Electoral Studies, 30(1), 16-28.

de Wilde, P. (2011). No polity for old politics? A framework for analyzing the politicization of European integration. Journal of European Integration, 33, 559-575.

Dodeigne, J. (2015). Representing a minority group in multinational federal systems: Career patterns in 
Catalonia, Scotland and Wallonia. (Unpublished Doctoral dissertation) Université de Liège and Université Catholique de Louvain, Belgium.

Dorussen, H., \& Taylor, M. (2001). Economic voting. London: Routledge.

Duch, R. M., \& Stevenson, R. (2006). Assessing the magnitude of the economic vote over time and across nations. Electoral Studies, 25(3), 528-547.

Duchesne, S., Frazer, E., Haegel, F., \& Van Ingelgom, V. (2013). Citizens' reactions to European integration compared. Basingstoke: Palgrave Macmillan.

Ehin, P. (2008). Competing models of EU legitimacy: The test of popular expectations. Journal of Common Market Studies, 46(3), 619-640.

Evans, G. (1998). How Britain views the EU. In R. Jowell, J. Curtice, A. Park; L. Brook, K. Thomson \& C. Bryson (Eds.), British-and European-Social attitudes (15th Report). Aldershot: Ashgate.

Evans, G. (2002). European integration, party politics and voting in the 2001 election. British Elections \& Parties Review, 12(1), 95-110.

Fiorina, M. P. (1992). An era of divided government. Political Science Quarterly, 107(3), 387-410.

Fligstein, N. (2008). Euroclash: The EU, European identity and the future of Europe. Oxford: Oxford University Press.

Føllesdal, A., \& Hix, S. (2006). Why there is a democratic deficit in the EU: A response to Majone and Moravcsik. JCMS: Journal of Common Market Studies, 44(3), 533-562.

Giebler, H., \& Wagner, W. (2015). Contrasting first- and second-order electoral behaviour: Determinants of individual party choice in European and German Federal elections. German Politics, 24(1), 46-66.

Heath, A., McLean, I., Taylor, B., \& Curtice, J. (1999). Between first and second order: A comparison of voting behaviour in European and local elections in Britain. European Journal of Political Research, 35(3), 389-414.

Hix, S., \& Marsh, M. (2007). Punishment or protest? Understanding European Parliament elections. Journal of Politics, 69(2), 495-510.

Hobolt, S. B. (2014). A vote for the President? The role of Spitzenkandidaten in the 2014 European Parliament elections. Journal of European Public Policy, 21(10), 1528-1540.

Hobolt, S. B., Spoon, J.-J., \& Tilley, J. (2009). A vote against Europe? Explaining defection at the 1999 and 2004 European Parliament elections. British Journal of Political Science, 39(1), 93-115.

Hobolt, S. B., \& Tilley, J. (2014). Who's in charge? Voter attribution of responsibility in the European Union. Comparative Political Studies, 47(6), 795-819.

Hobolt, S. B., \& Wittrock, J. (2011). The second-order election model revisited: An experimental test of vote choices in European Parliament elections. Electoral Studies, 30(1), 29-40.

Hong, G. (2015). Explaining vote switching to niche par- ties in the 2009 European Parliament elections. European Union Politics. Retrieved from http://eup. sagepub.com/content/early/2015/06/02/146511651 5586428.abstract

Jacobson, G. (1990). The electoral origins of divided government. Boulder: Westview.

Jeffery, C., \& Hough, D. (2009). Understanding postdevolution elections in Scotland and Wales in comparative perspectives. Party Politics, 15(2), 219-240.

Kramer, G. H. (1971). Short-term fluctuations in U.S. voting behavior, 1896-1964. American Political Science Review, 65(1), 131-143.

Kriesi, H. \& Grande, E. (2015). Political debate in a polarizing Union. In O. Cramme \& S.B. Hobolt (Eds.), Democratic politics in a European Union under stress. Oxford: Oxford University Press.

Lewis-Beck, M. S. (1990). Economics and elections: The major Western democracies. University of Michigan Press.

Lewis-Beck, M. S., \& Stegmaier, M. (2000). Economic determinants of electoral outcomes. Annual Review of Political Science, 3(1), 183-219.

Marsh, M., \& Mikhaylov, S. (2010). European Parliament elections and EU governance. Living Reviews in European Governance, 5(4).

Mattila, M. (2003). Why bother? Determinants of turnout in the European elections. Electoral Studies, 22(3), 449-468.

Nannestad, P., \& Paldam, M. (1994). The VP-function: A survey of the literature on vote and popularity functions after 25 years. Public Choice, 79(3-4), 213-245.

Norpoth, H., Lewis-Beck, M. S., \& Lafay, J.-D. (1991). Economics and politics: The calculus of support. Michigan: University of Michigan Press.

Parodi, J.-L. (1983). Dans la logique des élections "intermédiaires". Revue Politique et Parlementaire, 84 (903), 42-70.

Reif, K. (1984). National electoral cycles and European elections 1979 and 1984. Electoral Studies, 3(3), 244 255.

Reif, K. (1985). Ten second-order national elections. In K. Reif (Eds.), Ten European elections. (pp. 1-36). Brookfield: Gower.

Reif, K., \& Schmitt, H. (1980). Nine second-order national elections: A conceptual framework for the analysis of European election results. European Journal of Political Research, 8(1), 3-44.

Rohrschneider, R., \& Loveless, M. (2011). Public perceptions of the EU as a system of governance. Living Reviews in European Governance (LREG), 6(2). Retrieved from https://ideas.repec.org/a/erp/lregxx/p0020.html

Roscoe, D. D. (2003). The choosers or the choices? Voter characteristics and the structure of electoral competition as explanations for ticket splitting. Journal of Politics, 65(4), 1147-1164.

Rose, R., \& Borz, G. (2015). Static and dynamic views of European integration. Journal of Common Market 
Studies, 1-18. doi: 10.1111/jcms.12295

Sautois, J., \& Uyttendaele, M. (2013). La sixième réforme de l'Etat 2012-2013. Tournant historique ou soubresaut ordinaire? Limal: Anthemis.

Schmitt, H. (2005). The European Parliament elections of June 2004: Still second-order? West European Politics, 28(3), 650-679.

Schuck, A., Xezonakis, G., Elenbaas, M., Banducci, S., \& de Vreese, C. (2011). Party contestation and Europe on the news agenda: The 2009 European Parliamentary elections. Electoral Studies, 30(1), 41-52.

Stoeckel, F. (2013). Ambivalent or indifferent? Reconsidering the structure of EU public opinion. European Union Politics, 14, 23-45.

Treib, O. (2014). The voter says no, but nobody listens: Causes and consequences of the Eurosceptic vote in the 2014 European elections. Journal of European Public Policy, 21(10), 1541-1554.

Van Aelst, P., \& Lefevere, J. (2012). Has Europe got anything to do with the European elections? A study on split-ticket voting in the Belgian regional and European elections of 2009. European Union Politics, 13(1), 3-25.

Van der Eijk, C., \& Franklin, M. (2004). Potential for contestation on European matters at national elections in Europe. In G. Marks \& M. Steenbergen (Eds.), Eu- ropean integration and political conflict. (pp. 32-50). Cambridge: Cambridge University Press.

Van der Eijk, C., Franklin, M., \& Marsh, M. (1996). What voters teach us about Europe-wide elections: What Europe-wide elections teach us about voters. Electoral Studies, 15(2), 243-260.

Van Ingelgom, V. (2012). Mesurer I'indifférence. Intégration européenne et attitudes des citoyens. Sociologie, 1, 1-20.

Van Ingelgom, V. (2014). Integrating indifference. A comparative, qualitative, and quantitative approach to the legitimacy of European integration. Colchester: ECPR Press.

Verhaegen, S. (2015). European identity and the perceived importance of European Parliament elections in Belgium. Presented at the MPSA General Conference 2015, Chicago.

Verhaegen, S., \& Hooghe, M. (2015). Does more knowledge about the European Union lead to a stronger European identity? A comparative analysis among adolescents in 21 European member states. Innovation: The European Journal of Social Science Research, 28(2), 127-146.

Wattenberg, M. P. (1991). The rise of candidate-centered politics: Presidential elections of the 1980s. Cambridge, MA: Harvard University Press.

\section{About the Authors}

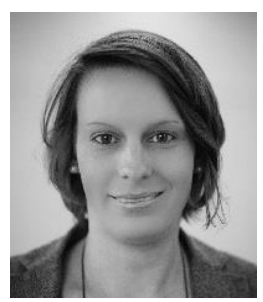

\section{Camille Kelbel}

Camille Kelbel is a PhD candidate at the Université Libre de Bruxelles, taking part in the 'PartiRep' Interuniversity Attraction Pole. Prior to joining the ULB, Camille Kelbel was an academic assistant at the College of Europe, Bruges. Her PhD project focuses on candidate selection for European elections. More generally, her research interests lie in EU politics, political parties and elections.

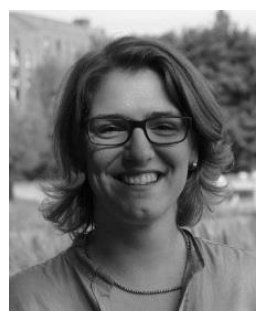

\section{Prof. Dr. Virginie Van Ingelgom}

Virginie Van Ingelgom is a Research Associate Professor F.R.S. - FNRS at the Institut de Sciences Politiques Louvain-Europe, Université Catholique de Louvain and an associate research fellow of the Centre for European Studies, Sciences Po Paris. Her research focuses on citizens' reactions and attitudes towards European integration and on EU legitimacy and its politicisation.

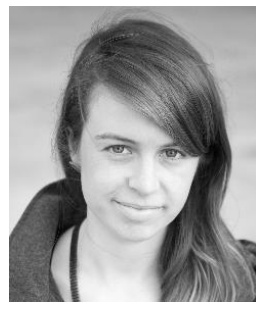

\section{Dr. Soetkin Verhaegen}

Soetkin Verhaegen is a postdoctoral researcher at the Centre for Political Science at KU Leuven. Her research focuses on the relationship between European identity and political and social attitudes and behaviour. 